\title{
Islamic Corporate Social Responsibility Towards Asset Optimization in Indonesia Sharia Commercial Banks
}

\author{
Dinda Fali Rifan ${ }^{1}$, Nur Wahyu Ningsih ${ }^{2}$ \\ \{email: dinda.falirifan@ radenintan.ac.id ${ }^{1}$, email: nurwahyu.ningsih107@gmail.com² ${ }^{2}$, \\ Raden Intan State Islamic University of Lampung, Jl. Letnal Kolonel Endro Suratmin, Sukarame, \\ Bandar Lampung ${ }^{1}$, \\ Raden Intan State Islamic University of Lampung, Jl. Letnal Kolonel Endro Suratmin, Sukarame, \\ Bandar Lampung ${ }^{2}$
}

\begin{abstract}
This study aims to examine the effect of Islamic Corporate Social Responsibility (ICSR) disclosures on asset optimization as measured by Return on Assets (ROA). This relationship is examined based on Simple Linier Regression analysis of eleven Sharia Commercial Banks annual reports in Financial Services Authority of Indonesia in the period of 2015-2017. This study also provides evidences that ICSR activities communicated in corporate annual reports are significantly related to asset optimization that measured by the Return on Assets (ROA).
\end{abstract}

Keywords: Islamic Corporate Social Responsibility (ICSR), Return on Assets (ROA), Sharia Commercials Banks.

\section{Introduction}

Social care and environmental care is one aspect of an institution that receives special attention from the public. This form of responsibility can usually be seen through the disclosure of corporate social responsibility contained in a report. For most institutions CSR reporting is still voluntary. However, for companies whose business activities are related to natural resources, they are required to carry out social and environmental responsibilities. The issue is based on Limited Liability Company Law Number 40 of 2007 [1]. The same development also occurred in Islamic economics, which in turn, also increased public attention towards Islamic institutions. Therefore, the public's need for information about Islamic institutions is getting bigger from time to time [2]. Corporate Social Responsibility in the perspective of Islam, is an inherent consequence of the teachings of Islamic law (maqashid al syariah) of which business is considered as an effort to bring benefit to the people (not just looking for profit) [3]. This idea is also supported by Sharia Enterprise Theory which is used to understand the company's stakeholders from an Islamic perspective. This kind of CSR concept is commonly called Islamic Corporate Social Responsibility (ICSR). According to [2] the concept of ICSR is a development of conventional Corporate Social Responsibility by incorporating Islamic views.

One of the business institutions whose operational activities are based on sharia is sharia banking. According to [4] sharia banking has relevant social responsibilities to discuss due to several operational conditions imposed on them, such as moral, ethical and social responsibility. Some principles inherent in these responsibilities are based on the public interest, such as avoidance of losses (moral and material) and poverty. This statement is also 
supported by a verse in the Qur'an in the verse 77 of the Al-Qashash [5] concerning the prohibition to do any damage on earth. Therefore, today, Sharia Commercial Banks (BUS) are starting to steal public attention. According to [6], the perception of banking stakeholders on the implementation of ICSR gives a positive perception of CSR disclosure of sharia banking as they assume that CSR disclosure is one of the things that must be considered in choosing banking services.

Previous research on Islamic Corporate Social Responsibility was conducted by [7] with sharia banking in Malaysia as the object of research in the period of 2008-2010. The results of this study show that ICSR disclosure has a significant positive effect on the company's reputation and performance. Other research on Islamic Social Reporting was also conducted by [2] with Sharia Commercial Banks in Indonesia as research objects in the 2012-2015 period, showing that the disclosure of Islamic Social Reporting did not significantly influence Return on Assets. Other research also conducted by [8] in Indonesian sharia banking in the 2011-2013 period showing that the ICSR disclosure activity in the financial statements had no significant effect on ROA. The needs of stakeholders regarding the disclosure of social responsibility in sharia banking make ICSR, currently, widely discussed because it is believed to be a standard of CSR disclosure in accordance with an Islamic perspective. This makes the disclosure of ICSR something that needs to be considered by Sharia Commercial Banks in optimizing their assets to operate Sharia Commercial Banks' activities.

\section{Literature Review}

\subsection{Legitimacy Theory}

The concept of organizational legitimacy is defined by [9] that is used in accordance with the value system of the wider social system. Legitimacy theory explains that regulations, network of organization and norma influence the degree of voluntary disclosure.

\subsection{Stakeholder Theory}

Stakeholder theory states that companies combine various expectations of the stakeholders, stakeholders will be able to create extraordinary company performance [10]. According to [11] Stakeholder Theory is composed of several assumptions: (1) Organization has relationships with many stakeholder that influence and are influenced by entity decisions. This theory focuses on the nature of relationship in process and output for the company and the stakeholders, (2) The interests of all stakeholder legitimacy are of intrinsic value and do not form interests dominated by each other, and (3) This theory focuses on managerial decision making.

\subsection{Sharia Enterprise Theory}

Sharia Enterprise Theory (SET) is used to understand corporate stakeholders from an Islamic perspective. SET asserts that corporate stakeholders include not only for humans, but also the natural environment, and God. Humans are ultimately responsible to God for all their activities in the world [12]. Sharia Enterprise Theory (SET) that the most appropriate theory to express corporate social responsibility in the case of sharia banking, God is the main trustee source, while the resources owned by the stakeholders are something that is mandated by God in which a responsibility to use them in manners and purposes set by the Supreme Being is attached [13]. 


\subsection{Islamic Corporate Social Responsibility (ICSR)}

ICSR is a CSR concept that emphasizes the spiritual approach as the basis of the company's obligation to be socially responsible to the surrounding environment, both the natural environment and society [14]. The concept of ICSR disclosure carried out by Islamic financial institutions must cover all activities aimed at ICSR objects, namely nature, direct stakeholders, and indirect stakeholders. Because of the importance of the ICSR, it is hoped that Islamic organizations will be selective in choosing members of management and councils in determining certain qualifications and religious belief for implementing ICSR disclosure initiatives [15]. Sharia banking are expected to describe a high level of corporate social responsibility and are clear in their social reporting practices as evidenced in annual [16]. ICSR can improve a company's reputation as well as company performance [8]. But the goal of stakeholders in companies and sharia banking is expected not only to pursue profit alone, but rather to the pure realization as a responsible caliph on earth. According to [17] in Islam, business activities are not only a matter of fulfilling material needs and desires but also about fulfilling religious responsibilities.

\subsection{Return on Asset (ROA)}

Financial performance illustrates the role in increasing the activities offered by sharia banking to investors. The transformation from several conventional banks to sharia banking has created a good reputation for investors through a good ICSR [18]. Profitability ratios explain the company's activity in generating maximum profit. For long-term investors, the profit ratio aims to see dividends [19]. ROA determines how effective management generating profits with the total assets. ROA can be calculated through the comparison of income after tax with the company's total assets. A higher percentage of ROA indicates that management is better at generating profits with total asset [6]. Some studied shows that CSR has a positive impact to ROA. CSR has become an important driver in influencing the opinions of stakeholders regarding the fulfillment of corporate obligations [20]. For this reason, hypothesis is:

$\mathrm{Ha}_{1}$ : ICSR has significant impact on ROA

\section{Methodology}

\subsection{Sampling, Data Types and Sources}

The method for selecting the sample of this study was purposive judgment sampling. The criteria that use in determining the research sample are Sharia Commercial Banks listed on the Financial Services Authority of Indonesia who publish annual reports on www.ojk.go.id in the 2015-2017 period, and disclose ICSR in annual report. Based on these criteria, a total sample of eleven Sharia Commercial Banks in Indonesia was selected. This study used secondary data and ROA data in the annual report and ICSR reports from eleven Sharia Commercial Banks in Indonesia the 2015-2017 period.

\subsection{Operational Definition and Variable Measurement}

The dependent variable in this study is financial performance projected by ROA. Formulas of ROA is: 
Meanwhile, the independent variable is the disclosure of ICSR. ICSR disclosure is measured by social disclosure index which is a dummy variable. ICSR disclosure formula is as follows: [21]

$$
\operatorname{ICSRD}_{\mathrm{j}}=\frac{\sum X_{l j}}{\mathrm{n}_{\mathrm{j}}}
$$

Where:

ICSRD Ij : ICSR Disclosure Index Sharia Commercial Bank $\mathrm{j} . ; \mathrm{Nj}$ : number of items for the company $\mathrm{j}, \mathrm{nj}=38 ; \mathrm{Xij}: 1=$ if item $i$ disclosed; $0=$ if item $i$ is not disclosed. $0 \leq \mathrm{Ij} \geq 1$.

To measure the application of ICSR in Sharia Commercial Banks in Indonesia, this study uses the Islamic Social Reporting Index (ISR Index), consisting of 38 items of sharia commercial banking social performance standards [22].

\subsection{Analytical Method}

The analytical method that used is simple linear regression.

$$
\mathrm{Y}_{1}=\alpha_{1}+\beta_{1} \mathrm{X}_{1+} \mathrm{e}
$$

Where:

$\mathrm{Y}_{1}=\mathrm{ICSR} ; \mathrm{X}_{1}=R O A ; \alpha=$ Constants; $\beta_{1}=$ Regression Coefficient; $\mathrm{e}=$ Error

\subsection{Hypothesis Testing}

Testing the hypothesis in this study uses a $95 \%$ confidence level and a 5\% error rate. The basis for decision making is profitability. If p-value> 0.05 then $\mathrm{Ho}$ is accepted and $\mathrm{Ha}$ is rejected and if the p-value is $<0.05$ then Ho is rejected and Ha is accepted.

\subsection{Research Model}

The research model is as follows:

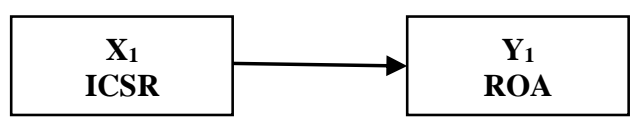

Fig 1. Research Model. 


\section{Discussion}

\subsection{Hypothesis Testing Result}

I tested the classic assumptions before testing the hypothesis. The normality statistical test was performed using One-Sample Kolmogorov-Smirnov Z (K-S) with the dependent variable ROA. In the test results, the significance value for stock returns is 0.194 , or greater than 0.05 . It indicates that the return variable is normally distributed. Here are the result of the normality test:

Table 1. The Result of One-Sample Kolmogorov-Smirnov Test.

\begin{tabular}{lr}
\hline & Unstandardized Residual \\
\hline $\mathrm{N}$ & 33 \\
Kolmogorov-Smirnov Z & 1.080 \\
Asymp. Sig. (2-tailed) & .194 \\
\hline
\end{tabular}

a. Test distribution is Normal.

Another test of classical assumptions on ROA variables shows that the results meet linearity requirements and there is no autocorrelation and heteroscedasticity. Because the data is normally distributed, it is tested to test the hypothesis whether there is a positive relationship between the ICSR variable and the ROA variable.

\subsection{Test of the Effect of ICSR on ROA}

The following is the result of the goodness of fit testing of the ROA variable:

Table 2. Goodness of Fit Test Result.

\begin{tabular}{lrrrrr}
\hline Model & R & R Square & Adjusted R Square & Std. Error of the Estimate \\
1 & $.975^{\mathrm{a}}$ & .950 & .949 & .06898 \\
\hline a. Predictors: (Constant), ICSR & & & \\
b. Dependent Variable: ROA & & &
\end{tabular}

The table above shows that the adjusted $\mathrm{R}^{2}$ is 0.950 . This indicates that $95 \%$ variation in ROA can be explained by ICSR variables and the remaining $5 \%$ is explained by other variables outside the research model.

Table 3. Hypothesis Testing Result.

\begin{tabular}{|c|c|c|c|c|c|c|}
\hline \multirow[b]{2}{*}{ Model } & & \multicolumn{2}{|c|}{ Unstd. Coeff. } & \multicolumn{3}{|l|}{ Std. Coeff. } \\
\hline & & B & Std. Error & Beta & $\mathrm{t}$ & Sig. \\
\hline 1 & (Constant) & .385 & .012 & & 32.026 & .000 \\
\hline & Unstd. Res. & 1.000 & .041 & .975 & 24.347 & .000 \\
\hline
\end{tabular}

a. Dependent Variable: ROA

Based on the results of the simple linear regression test, it can be concluded that ICSR variables have a positive and significant effect on ROA. This means that $\mathrm{Ha}_{1}$ is accepted. 


\section{Conclusions}

The results of this study indicate that the Islamic Corporate Social Responsibility (ICSR) variable influences ROA. Therefore, the greater the ICSR disclosed by a Sharia Commercial Banks, the higher the optimization of assets in generating profits.

\section{References}

[1] Undang-Undang Republik Indonesia Nomor 40 Tahun 2007: Undang-Undang Republik Perseroan Terbatas (2007)

[2] Sidik, I and Reskino: Zakat and islamic corporate social responsibility: do these effect the performance of sharia banks? Journal of Economics and Business. Vol. 1 No. 2 (2016)

[3] Syukron, A: CSR dalam perspektif islam dan perbankan. Jurnal Ekonomi dan Hukum Islam. Vol. 5 No. 1, pp. 1-22 ( 2015)

[4] H. Sofyani and A. Setiawan: Perbankan Syariah dan Tanggungjawab Sosial: Sebuah Studi Komparasi Indonesia dan Malaysia Dengan Pendekatan Islamic Social Reporting Index dan Global Reporting Initiative Index. At-Taradhi. Vol. 5 No. 2 (2015)

[5] Quran.com: The Noble Quran. ( 2016)

[6] J. C. Van Horne and J. John M. Wachowicz: Fundamentals of Financial Management 13th Edition. (2013)

[7] R. Arshad, S. Othman, and R. Othman: Islamic Corporate Social Responsibility, Corporate Reputation and Performance. Proc. World Acad. Sci. Eng. Technol. Vol. 6 No. 4, pp. 643-647. (2012)

[8] J. Arifin and E. A. Wardani: Islamic corporat social responsibility disclosure, reputasi, dan kinerja keuangan: Studi pada bank syariah di Indonesia. Jurnal Akuntansi dan Auditing Indonesia. Vol. 20 No. 1, pp.37-46. (2016)

[9] J. Dowling and J. Pfeffer: Organizational legitimacy: Social values and organizational behavior. Sociol Perspect. (1975)

[10] R. E. Freeman: Strategic Management: A Stakeholder Perspective. (1984)

[11] J. Andrew and C. Cortese: Accounting for climate change and the self-regulation of carbon disclosures. Account. Forum. Vol. 35 No. 3, pp. 130-138. (2011)

[12] I. Triyuwono: Akuntansi syariah dan koperasi mencari bentuk dalam metafora amanah. Jurnal Akuntansi dan Auditing Indonesia. Vol. 1 No. 1, pp.1-46. ( 1997)

[13] I. Meutia: The Concept of Social Responsibility Disclosures for Islamic Banks based on Shari'ah Enterprise Theory. J. Akunt. Multiparadigma. (2010)

[14] R. Reskino: Zakat and Islamic Corporate Social Responsibility: Does It Take Effect to the Performance of Shari'a Banking?. Shirkah J. Econ. Bus. ( 2016)

[15] Advances in Accounting Behavioral Research. (2014)

[16] Zubairu, U., M. Sakariyau, and C.K. Dauda: Social Reporting Practices of Islamic Banks in Saudi Arabia. Int. J. Bus. Soc. Sci. Vol. 2 No. 23, pp. 193-205 (2011)

[17] U. M. Chapra: Islam and the Economic Challenge. (1995)

[18] A. S. Musibah and W. S. B. W. Y. Alfattani: The mediating effect of financial performance on the relationship between shariah supervisory board effectiveness, intellectual capital and corporate social responsibility, of islamic banks in gulf cooperation council countries. Asian Soc. Sci. Vol. 10 No. 17, pp. 139-194. (2014)

[19] R. H. Smith, A. Tafti, I. Bardhan, and J. M. Goh: Information Technology And Firm Profitability: Mechanisms And Empirical Evidence 1 Sunil Mithas Theoretical Framework Background. El Sawy Pavlou. Vol. 36 No. 1, pp. 205-224. (2012)

[20] Deegan, M. Rankin, and J. Tobin: An examination of the corporate social and environmental disclosures of BHP from 1983-1997: A test of legitimacy theory. Accounting, Auditing \& Accountability Journal. Vol. 15 No. 3, pp. 312-343. (2002)

[21] Global Reporting Initiative G4: Reporting Principles and Standard Disclosures. J. Chem. Inf. 
Model. (2013)

[22] T. Vinnicombe: AAOIFI reporting standards: Measuring compliance. Adv. Account. (2010) 